\title{
CLAY INTERCALATED CU(II) AMINO ACID COMPLEXES: SYNTHESIS, SPECTROSCOPY AND CATALYSIS
}

\author{
L. FU, B. M. WECKHUYSEN, A. A. VERBERCKMOES AND \\ R. A. SCHOONHEYDT \\ Centrum voor Oppervlaktechemie en Katalyse, Departement Interfasechemie, K.U.Leuven, Kardinaal Mercierlaan 92, \\ 3001 Heverlee (Leuven), Belgium
}

(Received 23 February 1996; revised 7 May 1996)

\begin{abstract}
Complexes of $\mathrm{Cu}(\mathrm{lysine})_{2}^{2+}$ and $\mathrm{Cu}(\text { histidine })_{2}^{2+}$ have been intercalated between the layers of saponite clays by a simple cation exchange procedure from aqueous solutions of preformed $\mathrm{Cu}(\text { amino acid })_{2}$-complexes. Successful immobilization was obtained with an amino acid: $\mathrm{Cu}^{2+}$ ratio of 5 , and a pH of 10 and 7.3 for lysine and histidine, respectively. The synthesized materials were investigated as powders and as thin films by electron spin resonance (ESR), diffuse reflectance spectroscopy (DRS) and X-ray diffraction (XRD). The light blue clays are characterized by an axially symmetric ESR spectrum with $\mathrm{A}_{/ /}=192 \mathrm{G}, \mathrm{g}_{/ /}=2.23$ and $\mathrm{g}_{\perp}=2.07$, and a $\mathrm{d}-\mathrm{d}$ absorption band around $600 \mathrm{~nm}$, due to the intercalated planar $\mathrm{Cu}^{2+}$-complexes. Ammonia interacts reversibly with these intercalated complexes, suggesting the presence of a free coordination site. The novel synthesized materials are active in various oxidation reactions with $t$-butyl hydroperoxide as oxidant.
\end{abstract}

Studies of the immobilization of transition metal ion complexes on inorganic surfaces have fundamental and practical importance. At the fundamental level, researchers want to establish the sorption mechanism, the geometry of the adsorbed complex, the surface-complex interaction and the reactivity of the adsorbed complex. The main goal is to establish the differences between the sorbed complexes and their counterparts in solution and to make use of these differences. Immobilization of transition metal ion complexes also has practical importance in: (1) environmental science, as the complexes may $r$; extremely selectively and strongly adsorbed, thus leading to efficient removal and immobilization of transition metal ions; and (2) heterogeneous catalysis, as immobilized homogeneous catalysts have a number of well known advantages, such as the ease of separation of catalyst from reaction mixture and the use of an extended temperature range.

In the case of immobilization on clay surfaces, the field of study blossomed in the seventies. The exchange of $\mathrm{Ag}$ (thiourea) ${ }_{n}^{+}$on clays is not only an extremely efficient method to remove $\mathrm{Ag}^{+}$from waste waters, but could also be turned into a versatile method to determine the cation exchange capacity (CEC) of clays and soils (Cremers \&
Pleysier, 1973; Chhabra et al., 1975). The $\mathrm{Cu}$ (ethylenediamine) ${ }_{2}^{2+}$ in particular, and aliphatic polyamine complexes of $\mathrm{Cu}^{2+}$ and $\mathrm{Ni}^{2+}$ in general have clay surface complexation constants which are three orders of magnitude greater than in solution (Maes et al., 1977, 1978; Maes \& Cremers, 1978). This observation was confirmed by spectroscopic measurements and lead to the rule 'planar surfaces prefer planar complexes' (Velghe et al., 1977). It was established that in the interlamellar space, any axially coordinated ligands are replaced by the surface, thus leading to an increase of in-plane ligand field strength, which is correlated with the extra stabilization and expressed by the complexation constant (Maes et al., 1980). The $\mathrm{Ni}^{2+}$ aliphatic amine complexes are even turned into their diamagnetic square planar form (Schoonheydt et al., 1979a, 1979b).

In the case of amino acid (AA) complexes, the situation is more complex, because (1) coordination is possible through $\mathrm{NH}_{2}$ and carboxyl groups; (2) the positive charge of the complex, if any, may be located on the AA instead of on $\mathrm{Cu}^{2+}$; and (3) complexation is strongly pH-dependent (Wilson et al., 1970; Williams, 1971; Sigel \& Cormick, 1971; Yamauchi et al., 1979; Fisher \& Sigel, 1980). Here, we study the direct exchange of $\mathrm{Cu}(\text { lysine })_{2}^{n^{+}}$ 
and $\mathrm{Cu}$ (histidine $)_{2}^{n+}$ complexes onto saponite clays. The positive charge $n$ of the exchanged complexes is determined from the stoichiometry of the ion exchange reaction, while the nature of the first coordination sphere of $\mathrm{Cu}^{2+}$ is revealed by diffuse reflectance spectroscopy (DRS) and electron spin resonance (ESR). The reactivity of the immobilized complexes has been studied in liquid phase oxidation reactions in the presence of peroxides. The results are compared with those previously obtained using zeolites (Weckhuysen et al., 1995, 1996)

\section{EXPERIMENTAL}

\section{Synthesis}

Saponite with a CEC of $0.67 \mathrm{mEq} \mathrm{g^{-1 }}$ and a particle size of $\leqslant 2 \mu \mathrm{m}$ was used for cation exchange with preformed $\mathrm{Cu}(\mathrm{AA})_{\mathrm{n}}$ complexes. Solutions of $\mathrm{Cu}(\mathrm{AA})_{\mathrm{n}}$ were prepared by mixing $\mathrm{Cu}\left(\mathrm{NO}_{3}\right)_{2} \cdot 3 \mathrm{H}_{2} \mathrm{O}$ (Merck; AR) and AA (L-histidine and $\mathrm{L}-(+)-$ lysine, both from Janssen Chimica) at a $\mathrm{AA}: \mathrm{Cu}^{2+}$ molar ratio of 5 in distilled water $\left(\left[\mathrm{Cu}^{2+}=\right.\right.$ $\left.1 \times 10^{-3} \mathrm{M}\right)$. Pre-determined aliquots of these solutions were taken and adjusted to $50 \mathrm{ml}$ and to an ionic strength of $2 \times 10^{-3} \mathrm{M}$ using correct amounts of a $\mathrm{NaCl}$ solution. The initial $\mathrm{pH}$ was $\sim 6.0$ and 9.7 for the $\mathrm{Cu}$ (histidine) and $\mathrm{Cu}$ (lysine) solutions, respectively. The $\mathrm{pH}$ of these exchange solutions was then adjusted to 7.3 for the $\mathrm{Cu}$ (histidine) series, and to 10 for the $\mathrm{Cu}$ (lysine) series with drops of $\mathrm{NaOH}$. The ion exchange isotherms were established by mixing $30 \mathrm{ml}$ of the $\mathrm{Cu}(\mathrm{AA})_{\mathrm{n}}$ solution with $5 \mathrm{ml}$ of $1 \%$ saponite suspension at room temperature for $15 \mathrm{~h}$ on an end-over-end shaker. The solid phases were subsequently separated by centrifugation, washed three times with deionized water $(\mathrm{pH}=6)$ and freeze-dried. The clay samples were light blue. The $\mathrm{Cu}^{2+}$ and $\mathrm{Na}^{+}$contents of the initial solutions and the supernatants obtained after centrifugation were analysed by atomic absorption spectroscopy (AAS) in a $\mathrm{N}_{2} \mathrm{O}-\mathrm{C}_{2} \mathrm{H}_{2}$ flame at $324.7 \mathrm{~nm}$ and $589.6 \mathrm{~nm}$, respectively. The light source was a hollow cathode lamp with a wavelength of 589.6 and $324.7 \mathrm{~nm}$ for $\mathrm{Na}^{+}$and $\mathrm{Cu}^{2+}$, respectively. The histidine or lysine contents were determined indirectly via the $\mathrm{N}$ content by the micro-Kjeldahl method after dissolving known quantities of the clay material in $0.05 \mathrm{M}$ sulphuric acid with $\mathrm{Se}$ as a catalyst.

\section{Characterization}

The DRS spectra of powdered samples were taken on a Varian Cary 5 UV-Vis-NIR spectrophotometer at room temperature. The freeze-dried clay materials were loaded in a quartz flow cell with a Suprasil window and a capillary side-arm for DRS and ESR measurements, respectively. This cell enables measurement of the samples under controlled atmospheres. The spectra were recorded against a halon white reflectance standard in the range $2500-200 \mathrm{~nm}$. The spectra in Kubelka-Munk (KM) function were acquired by computer processing as explained elsewhere (Weckhuysen et al., 1993). The ESR spectra were recorded in X-band at a microwave power of $200 \mu \mathrm{W}$ on a Bruker ESP $300 \mathrm{E}$ spectrometer with a double rectangular $\mathrm{TE}_{104}$ mode cavity. The freeze-dried samples were

TABLE 1. $\mathrm{Cu}^{2+}$ and amino-acid uptake and $\mathrm{Na}^{+}$release.

\begin{tabular}{lcccccc}
\hline Sample name & $\begin{array}{c}\mathrm{Cu}^{2+} \text { init } \\
\mathrm{mmol} \mathrm{g}^{-1}\end{array}$ & $\begin{array}{c}{\left[\mathrm{Na}^{+}\right]_{\text {rel }}} \\
\mathrm{mmmol} \mathrm{g}\end{array}$ & $\begin{array}{c}{\left[\mathrm{Cu}^{2+}\right]_{\text {ads }}} \\
\mathrm{mmol} \mathrm{g}^{-1}\end{array}$ & $\begin{array}{c}\mathrm{AA}_{\text {ads }} \\
\mathrm{mmol} \mathrm{g}^{-1}\end{array}$ & {$\left[\mathrm{AA}_{\text {ads }}:\left[\mathrm{Cu}^{2+}\right]_{\text {ads }}\right.$} & {$\left[\mathrm{Na}^{+}\right]_{\mathrm{rel}}:\left[\mathrm{Cu}^{2+}\right]_{\text {ads }}$} \\
\hline CUHIS1 & 0.103 & 0.133 & 0.0560 & 0.126 & 2.25 & 2.38 \\
CUHIS2 & 0.308 & 0.210 & 0.0880 & 0.19 & 2.15 & 2.39 \\
CUHIS3 & 0.513 & 0.218 & 0.125 & 0.242 & 1.94 & 1.74 \\
CUHIS4 & 0.718 & 0.316 & 0.170 & - & - & 2.86 \\
CUHIS5 & 0.975 & 0.262 & 0.120 & 0.193 & 1.61 & 3.6 \\
CULYS1 & 0.104 & 0.219 & 0.0610 & 0.123 & 2.02 & 2.09 \\
CULYS2 & 0.312 & 0.367 & 0.176 & 0.458 & 2.6 & 1.97 \\
CULYS3 & 0.508 & 0.608 & 0.308 & 0.692 & 2.25 & 2.08 \\
CULYS4 & 0.729 & 0.826 & 0.436 & 0.773 & 1.77 & \\
CULYS5 & 1.042 & 0.652 & 0.314 & 0.736 & 2.34 & \\
\hline
\end{tabular}


measured at 120 and $300 \mathrm{~K}$ after vacuum treatment at room temperature (evacuation time and pressure were $0.5 \mathrm{~h}$ and $10^{-3} \mathrm{~atm}$, respectively). Absolute spin concentrations were determined by comparison of ESR signal intensities with those of well ground $\mathrm{Cu}(\mathrm{acac})_{2} / \mathrm{KCl}$ (acac $=$ acetylacetonate) mixtures with known spin concentration. Gaseous $\mathrm{NH}_{3}$ was allowed to adsorb at room temperature for $15 \mathrm{~min}$ on the samples in the combined DRS-ESR quartz flow cell, followed by desorption at $50^{\circ} \mathrm{C}$. After adsorption and desorption, ESR and DRS spectra were recorded as described above. Clay films $(2 \times$ $3 \mathrm{~cm}$ ) were fixed onto the hollow part of an alumina frame. X-ray diffraction patterns were recorded on a Philips diffractometer with $\mathrm{Cu}-K \alpha$ radiation. The scan range was between 3 and $50^{\circ} 2 \theta$. Oriented clay films were prepared by re-suspension of the freeze-dried samples in $\mathrm{H}_{2} \mathrm{O}$ and spreading a few drops of the suspension ( $1 \mathrm{wt} \%$ ) on a mylar film, followed by slowly evaporating the water at room temperature. Strips of $0.2 \times 2.0 \mathrm{~cm}$ were cut and placed in the ESR tube. The ESR spectra were recorded at $150 \mathrm{~K}$ with the magnetic field either parallel or perpendicular to the clay films. Catalytic experiments were carried out in quartz reactors at atmospheric pressure and $60^{\circ} \mathrm{C}$. The reactants and products were separated on a CP-sil5 column (Chrompack) on a 5890 Hewlet Packard GC; 1-heptanol was used as external standard.

\section{RESULTS}

\section{Ion exchange of $\mathrm{Cu}(A A)_{\mathrm{n}}^{\mathrm{m}+}$ complexes}

By using an increasing amount of preformed $\mathrm{Cu}(\mathrm{AA})_{n}^{m+}$ complex in bidistilled water together with a fixed amount of saponite clay, the amount of $\mathrm{Na}^{+}$released, and the amount of $\mathrm{Cu}^{2+}$ taken up by the clay and the amount of $\mathrm{Cu}^{2+}$ remaining in the exchange solution were measured. The initial amount of $\mathrm{Cu}^{2+}\left(\left[\mathrm{Cu}^{2+}\right]_{\text {init }}\right)$, the amounts of released $\mathrm{Na}^{+}\left(\left[\mathrm{Na}^{+}\right]_{\mathrm{rel}}\right)$ and of $\mathrm{Cu}^{2+}\left(\left[\mathrm{Cu}^{2+}{ }_{\text {ads }}\right)\right.$ and $\mathrm{AA}$ ([AA $]_{\text {ads }}$ ) taken up by saponite, expressed by the ratios $[\mathrm{AA}]_{\text {ads }}:\left[\mathrm{Cu}^{2+}\right]_{\text {ads }}$ and $\left[\mathrm{Na}^{+}\right]_{\mathrm{rel}}:\left[\mathrm{Cu}^{2+}\right]_{\text {ads }}$ are summarized in Table 1 . The molar ratio $\left[\mathrm{Na}^{+}\right]_{\mathrm{rel}}:\left[\mathrm{Cu}^{2+}\right]_{\mathrm{ads}}$ is always close to 2 , suggesting that (1) the adsorption is an ion exchange process and (2) the positive charge on the complex is $\sim 2$. At the lowest exchange levels, however, the ratio is a bit larger. This is due to experimental errors because only small amounts of $\mathrm{Na}^{+}$are released. The analysis of the amount of adsorbed AA is much more erratic, but on average the ratio $[\mathrm{AA}]_{\text {ads }}:\left[\mathrm{Cu}^{2+}\right]_{\text {ads }}$ is $\sim 2$ for all ion exchange levels and for both lysine and histidine. Thus, $\mathrm{Cu}(\text { lysine })_{2}^{2+}$ and $\mathrm{Cu}$ (histidine $)_{2}^{2+}$ are the complexes on the clay. Table 1 also shows that the uptake of $\mathrm{Cu}$ (lysine $)_{2}{ }^{2+}$ is much more selective than that of $\mathrm{Cu}$ (histidine) ${ }_{2}^{2+}$. This means that under the same exchange conditions clay surfaces prefer $\mathrm{Cu}(\text { lysine })_{2}^{2+}$ over $\mathrm{Cu}$ (histidine $)_{2}^{2+}$ complexes.

\section{Spectroscopy of immobilized $\mathrm{Cu}(\mathrm{AA})_{2}^{2+}$ complexes}

The $\mathrm{Cu}(\mathrm{AA})_{2}^{2+}$ samples are light blue and a typical DRS spectrum of freeze-dried Cu(lysine $)_{2}^{2+}$ saponite sample is shown in Fig. 1. One broad $d-d$ absorption, asymmetric towards larger wavelengths, is observed with an absorption maximum between $550 \mathrm{~nm}$ and $600 \mathrm{~nm}$, the exact value depending on the loading. The corresponding X-band ESR spectra for intercalated $\mathrm{Cu}(\text { lysine })_{2}^{2+}$ and $\mathrm{Cu}$ (histidine $2_{2}^{2+}$ complexes are presented in Fig. 2. The spectra are axially symmetric with $\mathrm{g}_{/ /}=2.23, \mathrm{~A}=192 \mathrm{G}$ and $\mathrm{g}_{\perp}=2.07$. The spectroscopic parameters are summarized in Table 2, together with those of some reference materials. Both the DRS and the ESR spectra are typical for planar coordination with both $\mathrm{N}$ and $\mathrm{O}$ in the first coordination sphere around $\mathrm{Cu}^{2+}$ (Lever, 1984; Abragam \& Bleaney, 1970; Pilbrow, 1990). For saponite intercalated $\mathrm{Cu}$ (histidine) $)_{2}^{2+}$ complexes, a second but weak signal is apparent, especially at low $\mathrm{Cu}$ loading. This signal looks like a pseudo-tetrahedral signal of $\mathrm{Cu}^{2+}$ with $\mathrm{g}_{\perp}>\mathrm{g}_{/ /}$(Abragam \& Bleaney, 1970; Pilbrow, 1990). The ESR spectra of the oriented films (Fig. 3) have clearly separated $\mathrm{g}_{/}$and $\mathrm{g}_{\perp}$ regions, without resolved hyperfine structure in the perpendicular region. This suggests that the clay particles are well oriented and that the $\mathrm{Cu}(\mathrm{AA})_{2}^{2+}$ complexes are located in the interlamellar space with their $\mathrm{Cu}(\mathrm{O}, \mathrm{N})$ plane parallel to the surface.

Upon adsorption of ammonia, the $\mathrm{d}-\mathrm{d}$ band maximum shifts to $655 \mathrm{~nm}$, but shifts back to its original position of $600 \mathrm{~nm}$ after evacuation at $50^{\circ} \mathrm{C}$ (Fig. 1). This red shift indicates a transition from a planar to a pseudo-octahedral complex upon adsorption of $\mathrm{NH}_{3}$. The coordination of ammonia can also be deduced from the corresponding ESR spectra of Fig. 4. Both for intercalated $\mathrm{Cu}(\mathrm{lysine})_{2}^{2+}$ and $\mathrm{Cu}$ (histidine) ${ }_{2}^{2+}$ saponite, the spectrum becomes more isotropic with $\mathrm{g}_{/ /}=2.25, \mathrm{~A}=170 \mathrm{G}$ and $\mathrm{g}_{1}=2.07$. Thus, combined DRS-ESR spectro- 


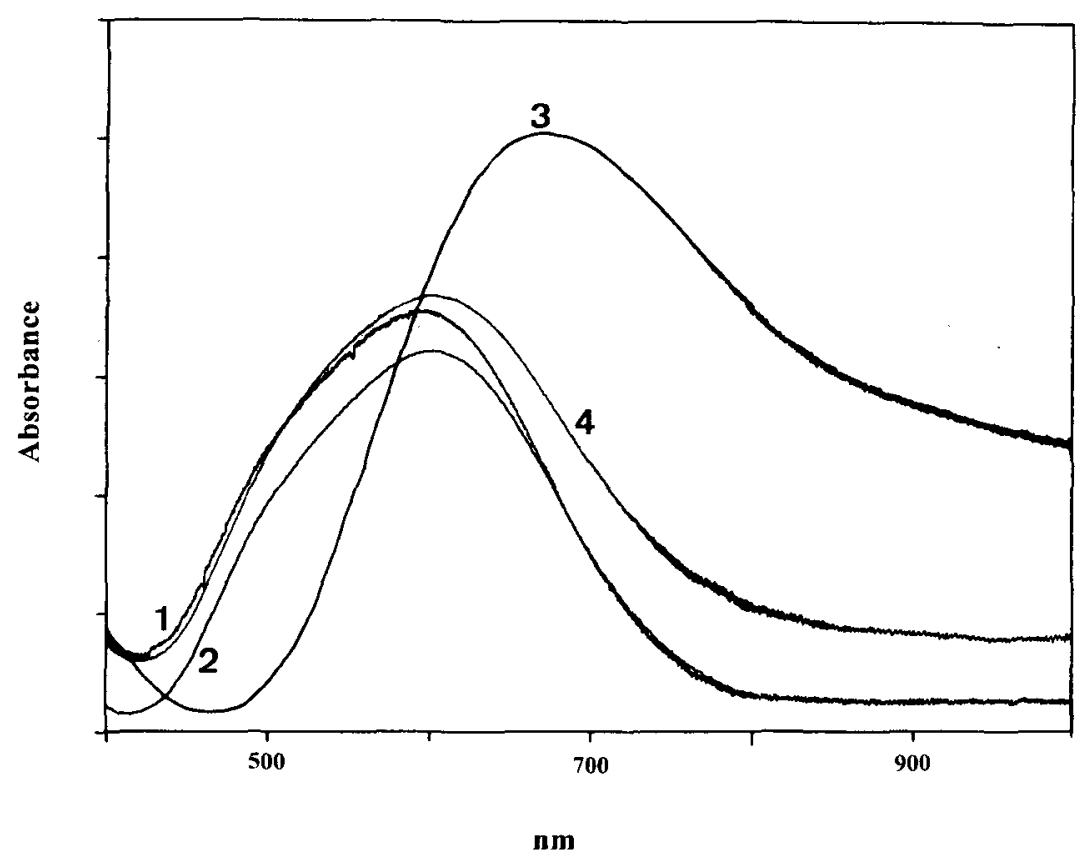

FIG. 1. DRS spectra of $\left[\mathrm{Cu}(\text { lysine })_{2}\right]^{2+}$-saponite materials (CULYS2) after different treatments: (1) as prepared; (2) dried at $50^{\circ} \mathrm{C}$; (3) after ammonia adsorption; and (4) after ammonia desorption.

scopies points to axial coordination of $\mathrm{NH}_{3}$, forming a pseudo-octahedral $\left[\mathrm{Cu}(\mathrm{AA})_{2}\left(\mathrm{NH}_{3}\right)_{2}^{2+}\right]$ complex. Finally, Fig. 5 shows that intercalation of the $\mathrm{Cu}(\mathrm{AA})_{2}^{2+}$ complexes between the clay layers results in a small increase in the $d_{001}$ line from 1.21 $\mathrm{nm}$ to $1.36 \mathrm{~nm}$, again confirming the planar nature of the complexes.

\section{Catalytic characterization of immobilized $\mathrm{Cu}(A A)_{2}^{2+}$ complexes}

The oxidation of alcohols and alkenes in the presence of $\left[\mathrm{Cu}(\text { histidine })_{2}^{2+}\right]-$ saponite (with a $\mathrm{Cu}^{2+}$ content of $0.122 \mathrm{mEqg}^{-1}$ ) with $t$-butyl hydroperoxide has been studied in detail at $60^{\circ} \mathrm{C}$ in batchtype reactors. The catalytic results of the $\left[\mathrm{Cu}(\mathrm{lysine})_{2}^{2+}\right]$-saponite system are inferior and will not be discussed further. The catalytic performances of the $\left[\mathrm{Cu}\right.$ (histidine) $\left.{ }_{2}^{2+}\right]$-saponite catalyst are summarized in Table 3 and compared with those of zeolite occluded $\mathrm{Cu}$ (histidine) complexes. Although the saponite-based catalyst is active in the oxidation of 1-pentanol, benzylalcohol and cyclohexene, the conversion is always lower than in the case of the zeolite occluded complexes (Weckhuysen et al., 1995). Furthermore, the

TABLE 2. Survey of the ESR parameters and DRS absorption bands of immobilized Cu(AA) complexes and reference materials.

\begin{tabular}{|c|c|c|c|c|c|}
\hline Material & $\mathrm{g} / /$ & $g_{\perp}$ & $\mathrm{A}_{/ /}(\mathrm{G})$ & $\mathrm{A}_{\perp, \mathrm{N}}(\mathrm{G})$ & $\mathrm{d}-\mathrm{d}$ absorption $\left(\mathrm{cm}^{-1}\right)$ \\
\hline $\mathrm{Cu}$-clay & 2.34 & 2.08 & 138 & - & 13,100 \\
\hline $\mathrm{Cu}-\mathrm{Y}$ & 2.40 & 2.09 & 134 & - & 12,500 \\
\hline$\left[\mathrm{Cu}(\text { lysine })_{2}\right]-$ clay & 2.23 & 2.07 & 192 & - & 16,700 \\
\hline$\left[\mathrm{Cu}(\text { lysine })_{2}\right]-\mathrm{Y}$ & 2.24 & 2.06 & 179 & - & 16,200 \\
\hline$\left.[\mathrm{Cu} \text { (histidine })_{2}\right]$-clay & 2.23 & 2.07 & 192 & - & 16,700 \\
\hline$\left[\mathrm{Cu}(\text { histidine })_{2}\right]-\mathrm{Y}$ & 2.27 & 2.06 & 178 & 13 & 15,600 \\
\hline
\end{tabular}




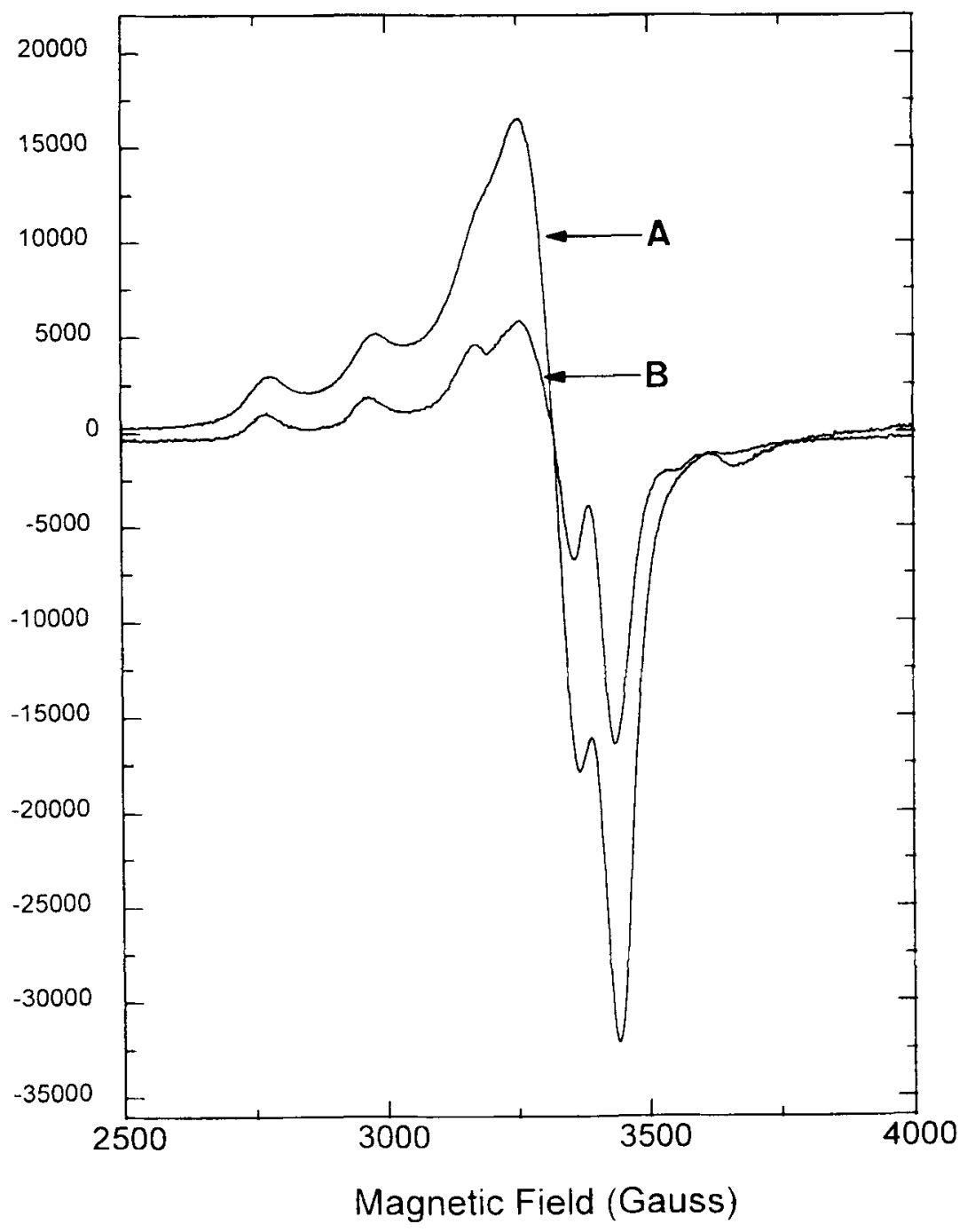

FIG. 2. ESR spectra of $\left[\mathrm{Cu}(\mathrm{AA})_{2}\right]^{2+}-$ saponite: (A) CULYS2 and (B) CUHIS2.

catalyst cannot be easily removed by centrifugation from the reaction mixture after reaction. This is due to some swelling of the clay material by the substrate and reaction products (Theng, 1974).

\section{DISCUSSION}

The aim of this discussion is: (1) to compare the coordination chemistry of intercalated $\mathrm{Cu}$ (lysine) and $\mathrm{Cu}$ (histidine) complexes with their analogues in solution and in the pore system of the zeolites; and
(2) to discuss the catalytic potential of the synthesized materials in oxidation catalysis.

Under the conditions of the present ion exchange, reactions $\mathrm{Cu}(\mathrm{lysine})_{2}^{2+}$ and $\mathrm{Cu}$ (histidine) $)_{2}^{2+}$ exist in aqueous solutions as pseudo-octahedral complexes. The first coordination sphere of the complexes consists of four inplane donor atoms and two more distant axial donor atoms. The exact composition of the first coordination sphere depends on the solution $\mathrm{pH}$, which determines the acid-base equilibria of the 

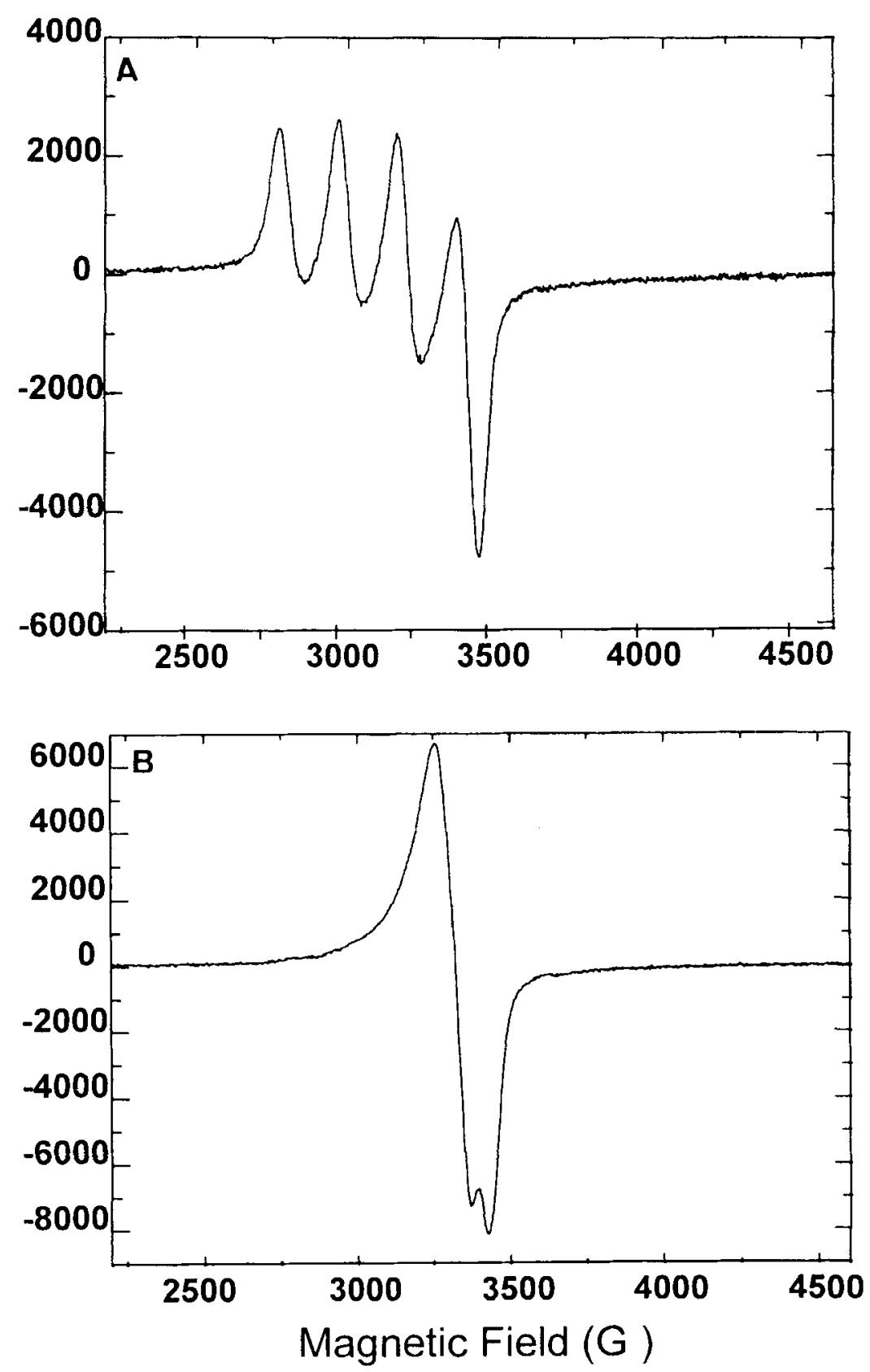

FIG. 3. ESR spectra of oriented films of $\left[\mathrm{Cu}(\text { lysine })_{2}\right]^{2+}$-saponite (CULYS2): (A) parallel with magnetic field; and (B) perpendicular to magnetic field.

functional groups $\left(\mathrm{NH}_{2}\right.$, imidazole and $\left.\mathrm{COOH}\right)$ of the amino acids lysine and histidine (Williams, 1971).
At a $\mathrm{pH}$ of 10 , the two lysine molecules are coordinated around $\mathrm{Cu}^{2+}$ in a glycine-like way, giving rise to a stable in plane NNOO coordination. 


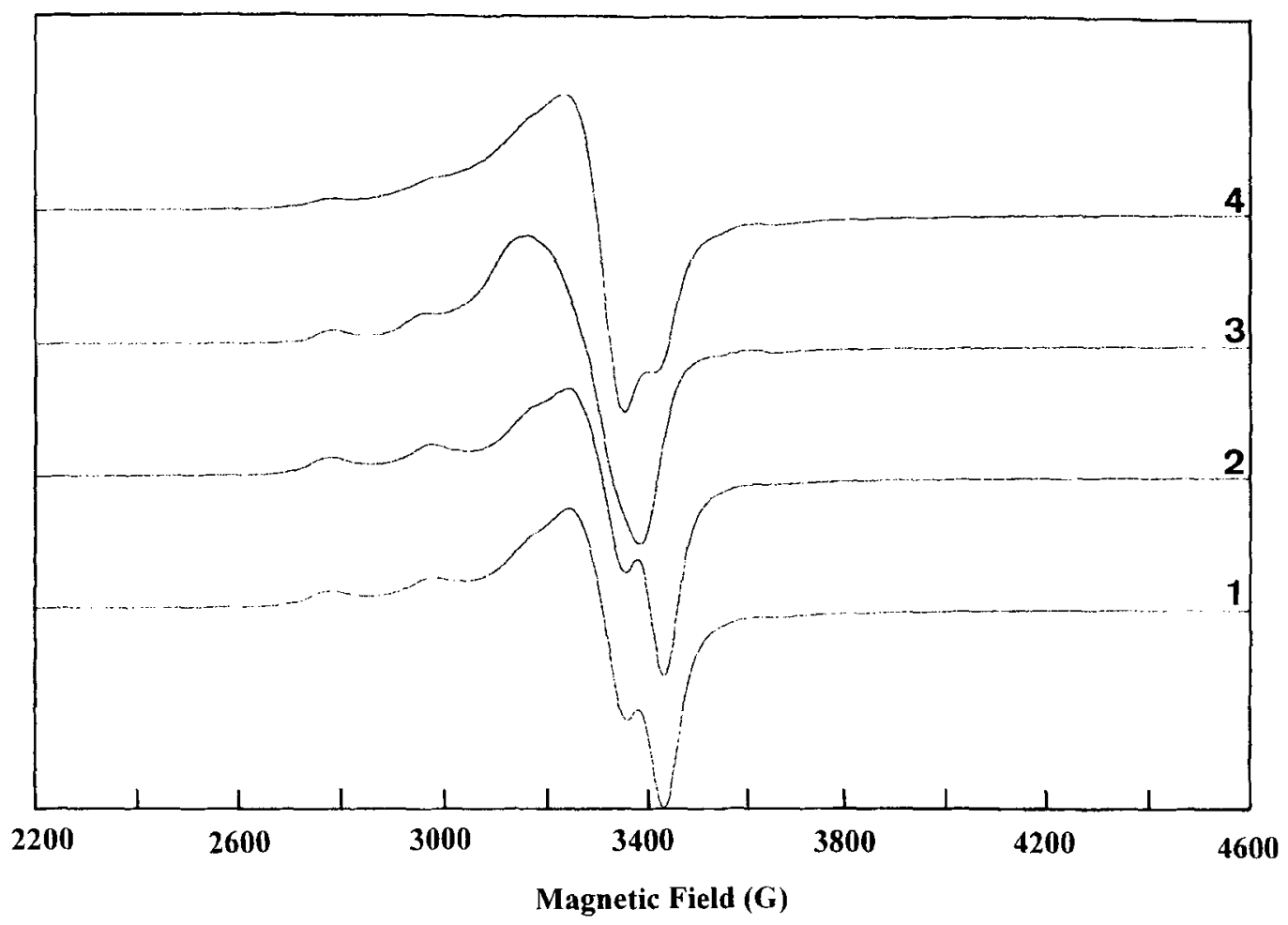

FIG. 4. ESR spectra of $\left[\mathrm{Cu}(\text { lysine })_{2}\right]^{2+}$-saponite materials after different treatments: (1) as prepared; (2) dried at $50^{\circ} \mathrm{C}$; (3) after ammonia adsorption; and (4) after ammonia desorption.

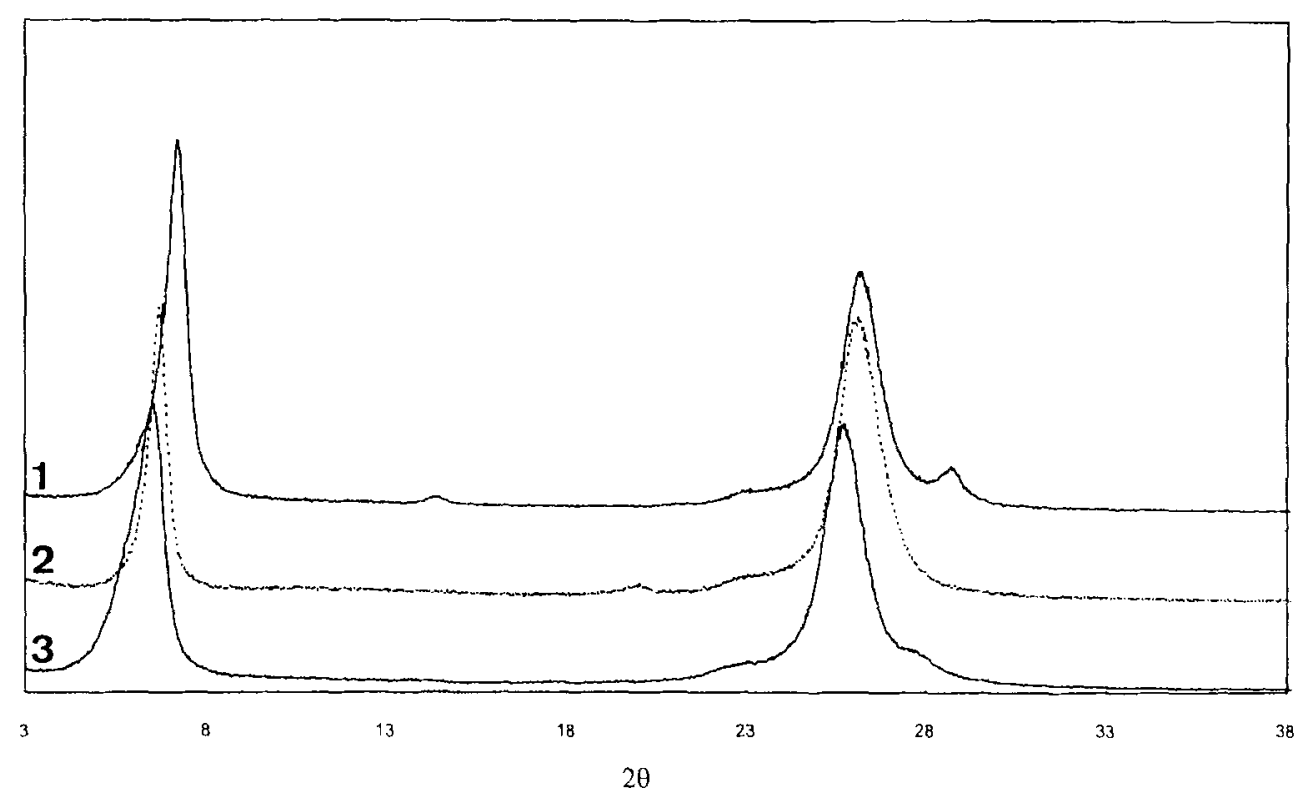

FIG. 5. XRD patterns of: (1) saponite clay; (2) $\left[\mathrm{Cu}(\mathrm{lysine})_{2}\right]^{2+}$-saponite; and (3) $\left.\mathrm{Cu}(\text { histidine })_{2}\right]^{2+}-$ saponite; $\mathrm{Cu}-K \alpha$ radiation. 
The net positive charge of the bis-complex is 2 because of the positive charge of the $\alpha$-amino group and the axial donor ligands are water molecules. At $\mathrm{pH} 7.5$, two histidine ligands are coordinated to $\mathrm{Cu}^{2+}$, one in a glycine-like way, the other in a histamine-like way and a stable NNNO coordination is obtained (Sigel \& Cormick, 1971). The axial donor ligands in both complexes are water molecules.

The adsorption is clearly an ion exchange reaction of divalent complexes without appreciable adsorption of free amino acid ligands. Both the DRS spectra and the EPR spectra are characteristic for tetragonally distorted octahedral or even square planar complexes. The $\mathrm{d}-\mathrm{d}$ transitions and EPR parameters of $\mathrm{Cu}(\text { lysine })_{2}$ and $\mathrm{Cu}$ (histidine $)_{2}$ immobilized on clays and zeolites are compared in Table 2 (Weckhuysen et al., 1995; 1996). The d-d band maxima are systematically higher in energy, the $g_{/ /}$values are lower and the $A_{/ /}$values higher for clays than for zeolites. All this indicates that the complexes are more planar-like on the bidimensional surface of saponite than in the supercages of zeolite $\mathrm{Y}$. This may be due to the removal of: (1) solvent $\left(\mathrm{H}_{2} \mathrm{O}\right)$ in axial positions; or (2) axially coordinating atoms of the amino acid. The former is likely to occur for lysine, the latter for the histidine complexes. This difference between both complexes might explain why the effect is more pronounced for histidine complexes. Nothing can be said about the in-plane coordinating atoms, because of the lack of $\mathrm{N}$-superhyperfine structure in the EPR spectra. We assume that in-plane coordination is as in solution, i.e. NNOO for lysine and NNNO for histidine. A schematic representation of the clay
(A)<smiles>NCCCCC(N)C(=O)OCC(N)C(=O)O</smiles>

(B)<smiles></smiles>

Fig. 6. Schematic representation of: (A) the clayintercalated $\left[\mathrm{Cu}(\text { lysine })_{2}\right]^{2+}$; and (B) $\left[\mathrm{Cu}(\text { lysine })_{2}\right]^{2+}$ complexes.

intercalated $\left[\mathrm{Cu}(\text { lysine })_{2}\right]^{2+}$ and $\left[\mathrm{Cu}(\text { lysine })_{2}\right]^{2+}$ complexes is shown in Fig. 6.

The intercalated complexes are accessible to ammonia, turning the planar $\mathrm{Cu}$-complexes into a distorted octahedral coordination and confirming the presence of a free coordination site, which is a necessity for catalysis. The catalytic activity of the $\mathrm{Cu}$ (histidine)-saponite system is compared in Table 3 with the $\mathrm{Cu}$ (histidine)-zeolite $\mathrm{Y}$ system obtained under exactly the same catalytic condi-

TABLE 3. Catalytic performances of $\mathrm{Cu}(\text { histidine })_{2}$ complexes intercalated in saponite and encaged in zeolite $\mathrm{Y}$ at $60^{\circ} \mathrm{C}$.

\begin{tabular}{llcc}
\hline Catalyst & Substrate & Time $(\mathrm{h})$ & Conversion $\left.^{(\mathrm{TON})}\right)^{2}$ \\
\hline Cu(histidine)-saponite & 1-pentanol & 24 & 243 \\
& benzylalcohol & 24 & 302 \\
& cyclohexene & 24 & 1008 \\
Cu(histidine)-Y & & 24 & 1425 \\
& 1-pentanol & 24 & 2421 \\
& benzylalcohol & 24 & 3232
\end{tabular}

100 mmole substrate and 150 mmole $t$-butylhydroperoxide.

${ }^{2}$ TON, turnover number. 
tions. The data clearly show that the prepared materials are active in oxidation reactions, especially in the epoxidation of cyclohexene. Thus, a new active catalyst, based on clay minerals, is developed for epoxidation reactions at relatively low temperatures. The catalytic performances, however, are inferior to those obtained with zeolite encapsulated $\mathrm{Cu}$ (histidine) complexes. This can be explained by: (1) the fact that not all complexes are available for reaction; and (2) the swelling of the clay material by the reaction products. The latter phenomena certainly complicates the regeneration of the developed catalyst and will limit its potential applications.

\section{CONCLUSIONS}

The main conclusions are: (1) Divalent biscomplexes of $\mathrm{Cu}$ (histidine) and $\mathrm{Cu}$ (lysine) can be intercalated in saponite clays by a simple ion exchange procedure of preformed $\mathrm{Cu}$-complexes. The exchanged $\mathrm{Cu}$ (amino acid) ${ }_{2}^{2+}$ complexes, present in the interlamellar spaces, have a planar NNOO/NNNO configuration. This finding confirms the rule that 'planar surfaces prefer planar complexes'. The intercalated complexes are accessible to ammonia, turning the $\mathrm{Cu}$-complexes into a distorted octahedral coordination and suggesting the presence of a free coordination site available for catalysis. (2) The new synthesized materials are active in the oxidation of pentanol, benzylalcohol and cyclohexene at low temperature with peroxides as oxidants. Their activity, however, is much lower than for zeolite occluded complexes and this lower activity is due in part to accessibility and in part to swelling of the clays by the reaction products.

\section{ACKNOWLEDGMENTS}

BMW and AAV acknowledge the Nationaal Fonds voor Wetenschappelijk Onderzoek (NFWO) and Instituut voor Wetenschap en Technologie (IWT) respectively for grants as research assistants. This work is supported by the Belgian Government in the frame of an Interuniversity Attraction Pole (IUAP).

\section{REFERENCES}

Abragam A. \& Bleaney B. (1970) Electron Paramagnetic Resonance of Transition Metal Ions. Clarendon Press, Oxford.

Chhabra R., Pleysier J. \& Cremers A. (1975) The measurement of the cation exchange capacity and exchangeable cations in soils: a new method. Proc. Int. Clay Conf. Mexico, 439-449.

Cremers A. \& Pleysier J. (1973) Adsorption of the silver-thiourea complex in montmorillonite. Nature Phys. Sci. 244, 86-87.

Fisher B.E. \& Sigel H. (1980) Ternary complexes in solution. 35. Intramolecular hydrophobic ligandligand interactions in mixed ligand complexes containing an aliphatic amino acid. J. Am. Chem. Soc. 102, 2998-3008.

LEVER A.B.P. (1984) Inorganic Electron Spectroscopy. Elsevier, 2nd edition, Amsterdam.

MAes A. \& CREMERS A. (1978) The stability of metal uncharged ligand complexes in ion exchangers. Part 3. Complex ion selectivity and stepwise stability constants. J. Chem. Soc., Faraday Trans. I, 74, 2470-2480.

MAes A., MARYNEn P. \& Cremers A. (1977) Stability of metal uncharged ligand complexes in ion exchangers. Part 1. Quantitative characterization and thermodynamic basis. J. Chem. Soc., Faraday Trans. I, 73, 1297-1301.

Maes A., Peigneur P. \& Cremers A. (1978) Stability of metal uncharged ligand complexes in ion exchangers. Part 2. The copper-ethylenediamine complex in montmorillonite and sulphonic acid resin. J. Chem. Soc., Faraday Trans. I, 74, 131-135.

Maes A., Schoonheydt R.A., Cremers A. \& UytTERhoEven J.B. (1980) Spectroscopy of $\mathrm{Cu}(\mathrm{en})_{2}^{2+}$ on clay surfaces: surface and charge density effects. J. Phys. Chem. 84, 2795-2799.

PILbRow J.R. (1990) Transition Ion Electron Paramagnetic Resonance. Clarendon Press, Oxford.

SChoonheydt R.A., Velghe F. \& UyTteRhoeven J.B. (1979a) Characterization of $\mathrm{Ni}(\mathrm{en})_{\mathrm{x}}^{2+}(\mathrm{x}=1,2,3$; en $=$ ethylenediamine) on the surface of montmorillonites. Inorg. Chem. 18, 1842-1847.

Schoonheydt R.A., Velghe F., Baerts R, \& UytTerhoeven J.B. (1979b) Complexes of diethylenetriamine (dien) and tetraethylenepentamine (tetren) with $\mathrm{Cu}(\mathrm{II})$ and $\mathrm{Ni}(\mathrm{II})$ on hectorite. Clays Clay Miner. 27, 269-278.

SIGEL H. \& CORMICK D.B. (1971) The structure of the copper(II)-L-histidine $1: 2$ complex in solution. $J$. Am. Chem. Soc. 93, $2041-2044$.

TheNG B.K.K. (1974) The Chemistry of Clay-Organic Reactions. Pp. 158-186. A. Hilger, London.

Velghe F., SchoonheydT R.A., UYTTERHOEVEN J.B., Petgneur P. \& Lunsford J.H. (1977) Spectroscopic characterization and thermal stability of Copper(II) ethylene-diamine complexes on solid surfaces 2 . Montmorillonite. J. Phys. Chem. 81, 1187-1194.

WECKHUYSEN B.M., DE RIDDER L.M. \& SCHOONHEYDT R.A. (1993) A quantitative diffuse reflectance spectroscopy study of supported chromium oxide catalysts. J. Phys. Chem. 97, 4756-4763. 
Weckhuysen B.M., Verberckmoes A.A., VanNiJVel I.P., Pelgrims J.A., Buskens P.L., Jacobs P.A. \& SCHOONHEYDT R.A. (1995) Zeolite encaged $\mathrm{Cu}$ (histidine) complexes as mimics of natural $\mathrm{Cu}$ enzymes. Angew. Chem. Int. Ed. Engl. 34, 2652-2654.

WeCKhuYSEN B.M., Verberckmoes A.A., Fu L. \& SchoonheydT R.A. (1996) Zeolite encapsulated copper(II)amino acid complexes : synthesis, spectroscopy and catalysis. J. Phys. Chem. 100, 9456-9461.
WILLIAMS D.R. (1971) The Metals of Life: the Solution Chemistry of Metal Ions in Biological Systems. Van Nostrand Reinhold Company, London.

Wilson E.W., Kasperian M.H. \& Martin R.B. (1970) Binding of copper(II) to potentially tridentate amino acid ligands. J. Am. Chem. Soc. 92, 5365-5372.

YAMAUChI O., SAKural T. \& NaKahara A. (1979) Histidine-containing ternary amino acid-copper(II) complexes. syntheses and properties. J. Am. Chem. Soc, 101, 4164-4172. 